Adam Ilciów

Uniwersytet Zielonogórski

\title{
Prezydent Legnicy. Kampania wyborcza w roku 2014
}

Streszczenie: Autor analizuje w artykule wybory samorządowe w 2014 roku. Skupia swoją uwagę głównie na rywalizacji o prezydenturę Legnicy pomiędzy dwoma najważniejszymi kontrkandydatami, urzędującym prezydentem Tadeuszem Krzakowskim i aspirującym do tej roli wiceprzewodniczącym lokalnych struktur partii rządzącej. Autor odwołuje się do założeń programowych obu kandydatów i analizuje przebieg kampanii. Poszukuje także czynników decydujących o sukcesie urzędującego prezydenta i porażce pretendenta do prezydentury Legnicy.

Słowa kluczowe: wybory samorządowe, prezydent miasta, Legnica, Tadeusz Krzakowski, Jarosław Rabczenko

\section{Wprowadzenie}

W ybory samorządowe często są przedmiotem analizy. O elekcjach w dolnośląskich miastach piszą wrocławscy politolodzy (Skrzypiński, 2012). Oceny wyborów na prezydentów miast zawiera opracowanie Prezydenci miast. Analiza rywalizacji $w$ wyborach samorzadowych (Tomczak, 2012). Tematykę tę podejmuje także, w szczególności analizując przypadki ponownego wyboru na prezydenta, Maciej Drzonek (Drzonek, 2013).

Wyniki wyborów samorządowych przedstawiane są w skali kraju, na ich podstawie generowane są wnioski o sukcesach lub porażkach partii reprezentowanych w parlamencie. Stosunkowo często pojawiają się także analizy wyborów w danym mieście (gminie) lub regionie. W przypadku wyborów prezydentów miast (burmistrzów, wójtów) koniecznym jest uzyskanie ponad 50\% głosów, bądź wygranie II tury wyborów z najlepszym kontrkandydatem. Zdarza się, że zwycięski kandydat uzyskuje niedużą przewagę ilości głosów.

Kandydaci na prezydentów miast często, nawet mimo wyraźnej afiliacji partyjnej, ubiegają się o ten urząd z własnego komitetu wyborczego. 
W komitecie tym są liderami, a w przypadku wyborczego sukcesu rezygnują z mandatu radnego. Silna reprezentacja ,prezydenckiego” komitetu w radzie może w dużym stopniu ułatwiać realizację zamierzeń. Polityczne ambicje kandydatów na prezydentów miast rosną. Ubiegają się także o mandaty radnych powiatu i mandaty radnych sejmików wojewódzkich. Jeśli nawet nie zdobywają silnej reprezentacji w radzie, mogą próbować zawierać koalicje, z pewnością radni wzmacniają znacząco pozycję prezydenta miasta (Ilciów, 2015).

Wybory samorządowe w roku 2014 dla wielu urzędujących prezydentów były trudnym sprawdzianem. Niejedna wygrana kampania i doświadczenie wynikające z pełnienia urzędu nawet przez kilka kadencji nie gwarantowały sukcesu.

Z chwilą przystąpienia Polski do Unii Europejskiej, osoby kandydujące w wyborach przedstawiały wizję uruchomienia wielu inwestycji finansowanych z funduszy europejskich. W wyborach samorządowych w roku 2006 receptą na zwycięstwo wydawała się być bezpartyjność kandydata. Tendencja ta utrzymywała się w kolejnych elekcjach, przybierając z czasem nieco karykaturalną formę. O ile można było bronić bezpartyjności kandydata, gdy ten występował z partii, o tyle kuriozalnym wydaje się kandydowanie $\mathrm{z}$ własnego komitetu i jednocześnie pełnienie funkcji przewodniczącego partii w mieście lub regionie (Ilciów, 2015).

Prezydenci miast dbają o swój wizerunek, utrzymują dobre relacje z mediami. Stale zabiegają o właściwą oprawę dla podejmowanych działań. Ubiegając się o ponowny wybór są w uprzywilejowanej pozycji, mogą wykorzystywać urząd dla promocji swojej kandydatury. W kampanii użytecznym może okazać się podsumowanie mijającej kadencji urzędującego prezydenta. Jeżeli rzeczywiście ma on się czym pochwalić, utrudni $\mathrm{w}$ ten sposób działania swoim politycznym przeciwnikom.

Prezydentom miast zarzuca się między innymi tworzenie w urzędach stanowisk pracy, które nie wynikają z potrzeb administracyjnych. Wskazuje się także na zagrożenia płynące z kontaktów prezydenta miasta z różnymi środowiskami, np. biznesowymi, naukowymi, kulturalnymi i społecznymi. Sugeruje się, że te powiązania mogą powodować brak przejrzystości w działaniach prezydenta. Do kompetencji prezydenta miasta należy między innymi planowanie zagospodarowania przestrzennego, zarządzanie gospodarką komunalną i systemem miejskiego transportu, decyduje on także o przekształceniach własnościowych (w mieście) oraz przyznaje dotacje. Niezadowolenie mieszkańców może pełnić 
funkcję katalizatora prowadzącego do podjęcia inicjatywy zmierzającej do skrócenia kadencji.

Duży zakres kompetencji prezydenta miasta uzasadnia się jego bezpośrednim wyborem, silną legitymizacją. Jednocześnie coraz częściej wskazuje się na negatywne aspekty pełnienia urzędu przez kilka kadencji. Krytycy obecnego rozwiązania uważają za konieczne ograniczenie kompetencji prezydenta miasta (tym samym wzmocnienie kompetencji radnych) oraz wprowadzenie limitu ilości kadencji.

Kampania wyborcza często przyjmuje formę rywalizacji pomiędzy urzędującym prezydentem, ubiegającym się o reelekcję, a pretendentami starającymi się przynajmniej doprowadzić do II tury wyborów. Sukcesy kończącej się kadencji może wskazywać prezydent miasta, niespełnione obietnice od ostatnich wyborów mogą wskazywać jego przeciwnicy. Ocena konkretnej sytuacji bywa uzależniona od punktu widzenia, sposobu przedstawienia przez media, wizerunkowej wiarygodności kandydatów. Kandydat broniący pozycji najczęściej unika konfrontacji z przeciwnikami. Wychodzi bowiem z założenia, że zbyt wiele w takim starciu może stracić. Do wyborczych debat z reguły dochodzi dopiero bezpośrednio przed II turą wyborów. Taka konfrontacja ,jeden na jeden” w większym stopniu polaryzuje stanowiska osób zainteresowanych kampanią wyborczą.

\section{Wybory prezydentów miast dolnośląskich w 2014 roku}

W województwie dolnośląskim prezydenci miast wybierani są w ośmiu miastach: Bolesławcu, Głogowie, Jeleniej Górze, Legnicy, Lubinie, Świdnicy, Wałbrzychu i Wrocławiu. W tabeli 1 przedstawiono uzyskane przez kandydatów rezultaty.

Tabela 1

Wyniki wyborów samorządowych w 2014 roku na prezydentów miast w województwie dolnośląskim

\begin{tabular}{||l|l|l|c|c|c||}
\hline Lp. & \multicolumn{1}{|c|}{ Miasto } & \multicolumn{1}{|c|}{ Prezydent } & $\begin{array}{c}\text { Tura } \\
\text { wyborów }\end{array}$ & $\begin{array}{c}\text { Wynik } \\
\text { wyborów }\end{array}$ & Reelekcja \\
\hline 1 & \multicolumn{1}{|c|}{2} & \multicolumn{1}{|c||}{3} & 4 & 5 & 6 \\
\hline 1 & Bolesławiec & Piotr Roman & I & $52,03 \%$ & $\mathrm{Re}$ \\
\hline 2 & Głogów & Rafael Rokaszewicz & II & $53,38 \%$ & - \\
\hline 3 & Jelenia Góra & Marcin Zawiła & II & $58,47 \%$ & $\operatorname{Re}$ \\
\hline 4 & Legnica & Tadeusz Krzakowski & II & $57,60 \%$ & Re \\
\hline 5 & Lubin & Robert Raczyński & I & $70,76 \%$ & Re \\
\hline
\end{tabular}




\begin{tabular}{||l|l|l|c|c|c||}
\hline 1 & \multicolumn{1}{|c|}{2} & \multicolumn{1}{|c|}{3} & 4 & 5 & 6 \\
\hline 6 & Świdnica & Beata Moskal-Słaniewska & II & $56,41 \%$ & - \\
\hline 7 & Wałbrzych & Roman Szełemej & I & $84,00 \%$ & $\mathrm{Re}^{*}$ \\
\hline 8 & Wrocław & Rafał Dutkiewicz & II & $54,72 \%$ & $\mathrm{Re}$ \\
\hline
\end{tabular}

Uwaga: Przez Re* oznaczono reelekcję Romana Szełemeja na stanowisku prezydenta Wałbrzycha. W wyborach samorządowych w roku 2010 prezydentem został Piotr Kruczkowski, jednak w maju 2011 roku został pozbawiony mandatu. Roman Szełemej w wyniku powołania przez premiera RP Donalda Tuska pełnił obowiązki prezydenta Wałbrzycha, a następnie wygrał przedterminowe wybory w sierpniu 2011 roku.

Źródło: Wizualizacja wyborów samorzq̨owych, http://pkw.gov.pl/wizualizacja-wyborow-samorzadowych-samorzad-2014/wizualizacja-wyborow-samorzadowych-info.html; Obwieszczenie komisarza wyborczego we Wrocławiu z dnia 1 grudnia 2014 r. uzupetniajace obwieszczenie z dnia 22 listopada 2014 r. (tekst jednolity Dz. U. 2014 poz. 5116) o wynikach wyborów wójtów, burmistrzów i prezydentów miast na obszarze województwa dolnoślaskiego, http://wroclaw.pkw.gov.pl/g2/oryginal/2014_12/d4d5c666536bd39a2915849d75864dc8.pdf.

W miastach dolnośląskich wybrano w I turze jedynie trzech spośród ośmiu prezydentów miast. Zaskoczeniem były sukcesy Rafaela Rokaszewicza w Głogowie i Beaty Moskal-Słaniewskiej w Świdnicy. Piotr Roman uzyskał wynik gorszy o 11,90\% w porównaniu z rezultatem sprzed 4 lat, Jan Zubowski przegrał wybory w II turze, Marcin Zawiła poprawił wynik o 3,90\%, Tadeusz Krzakowski potrzebował II tury, aby udowodnić swoją wyższość nad kontrkandydatem, Robert Raczyński potwierdził wysoko akceptację mieszkańców dla podejmowanych przez siebie działań (rezultat gorszy o 1,64\%), Rafał Dutkiewicz wysoki kapitał zaufania społecznego z poprzednich lat roztrwonił, uzyskując najgorszy wynik w porównaniu z wcześniejszymi wyborami. Jedynie w czterech miastach funkcję prezydenta od roku 2002 pełni ta sama osoba. Są to: Piotr Roman, Tadeusz Krzakowski, Robert Raczyński i Rafał Dutkiewicz (Ilciów, 2015).

\section{Kandydaci w wyborach na prezydenta Legnicy w 2014 roku}

W wyborach samorządowych w 2014 roku na prezydenta Legnicy kandydowało pięć osób: Jacek Bondarewicz, Tadeusz Krzakowski, Tymoteusz Myrda, Jarosław Rabczenko i Wacław Szetelnicki. W I turze wyborów uzyskali oni odpowiednio: 862, 13 448, 1477, 7895 i 6407 głosów. W II turze wyborów rywalizowali: Tadeusz Krzakowski i Jarosław Rab- 
czenko. Tadeusz Krzakowski zdobył poparcie 14394 osób, a Jarosław Rabczenko - 10597 osób (Wizualizacja; Obwieszczenie).

W roku 2014 prezydentem Legnicy został Tadeusz Krzakowski. Rozpoczął czwartą z kolei kadencję na tym stanowisku. Od 1982 roku należy do Związku Nauczycielstwa Polskiego, pełnił w nim funkcje wiceprzewodniczącego i przewodniczącego oddziału legnickiego. Pracował jako nauczyciel w szkołach w Pieńsku i Legnicy. W 1993 roku został dyrektorem Zespołu Szkół Integracyjnych im. Piastów Śląskich w Legnicy. W latach 1990-1998 był radnym Rady Miasta, w kadencji 1994-1998 pełnił funkcje jej przewodniczącego i wiceprzewodniczącego. W latach 1998-2002 był radnym i wiceprzewodniczącym sejmiku wojewódzkiego. Zanim wygrał wybory na prezydenta Legnicy w październiku 2002 roku, 3 miesiące wcześniej funkcję tę powierzyła mu Rada Miasta. Jest członkiem Sojuszu Lewicy Demokratycznej, w wyborach startował jednak z własnego komitetu (Strona internetowa Tadeusza Krzakowskiego (na potrzeby wyborów w roku 2014); Strona internetowa Tadeusza Krzakowskiego (jako prezydenta Legnicy); Profil Tadeusza Krzakowskiego na Facebooku, www.facebook.com/pages/Tadeusz-Krzakowski).

Do drugiej tury wyborów przeszedł Jarosław Rabczenko. Rozpoczął pracę zawodową od handlu i agencji reklamowej. W 2003 roku znalazł zatrudnienie w Agencji Rozwoju Regionalnego „Arleg” S.A., w której po 5 latach został członkiem zarządu, a w roku 2011 jej prezesem. Jarosław Rabczenko jest członkiem Platformy Obywatelskiej, od roku 2013 pełni funkcję wiceprzewodniczącego jej legnickich struktur. W wyborach w roku 2014 był kandydatem partyjnym, jednak jego materiały wyborcze nie zawierały loga partii. Został radnym Rady Miasta i przewodniczącym Klubu Radnych PO (Strona internetowa Jarosława Rabczenki; Profil Jarosława Rabczenki na Facebooku; Strona internetowa Biuletynu Informacji Publicznej Urzędu Miasta w Legnicy).

Trzeci w kolejności wynik w wyborach na prezydenta Legnicy uzyskał Wacław Szetelnicki. Był pracownikiem urzędu pracy, urzędu celnego, inspekcji sanitarnej oraz spółek KGHM Polska Miedź S.A. W samym KGHM S.A. pełnił funkcję dyrektora do spraw public relations. Od 2006 roku jest nauczycielem akademickim w PWSZ w Legnicy, w marcu 2015 roku został dziekanem Wydziału Nauk Społecznych i Humanistycznych tej uczelni. W wyborach w roku 2014 został radnym Rady Miasta, a następnie jej przewodniczącym (Strona internetowa Wacława Szetelnickiego; Profil Wacława Szetelnickiego na Facebooku; Strona internetowa Biuletynu Informacji Publicznej Urzędu Miasta w Legnicy). 
Kandydatem Bezpartyjnych Samorządowców na prezydenta Legnicy był Tymoteusz Myrda. W wyborach w latach 2010 i 2014 uzyskiwał mandat radnego sejmiku wojewódzkiego. Tymoteusz Myrda z wykształcenia jest prawnikiem, radcą prawnym. Powierzono mu obowiązki prokurenta i dyrektora do spraw rozwoju w MPWiK Sp. z o.o. w Lubinie oraz członka rady nadzorczej RTBS Sp. z o.o. w Lubinie. Pełnił funkcję sekretarza powiatu lubińskiego. W kadencji 2002-2006 był rzecznikiem prasowym prezydenta miasta Lubin i pełnomocnikiem do spraw nowych inwestorów (Strona internetowa Urzędu Marszałkowskiego Województwa Dolnośląskiego; Szymacha, 2014; Szymacha, 2015).

Jacek Bondarewicz kandydował w wyborach na prezydenta Legnicy w 2014 roku z komitetu Kongresu Nowej Prawicy. Prowadzi lokal gastronomiczny w Zielonej Górze. Pełni funkcję wiceprezesa zarządu regionu lubuskiego KNP, zorganizował struktury partii w Legnicy. Zainicjował działanie Fundacji Arche, jest jej wiceprezesem. Zasiada w Radzie Partnerstwa Porozumienia Platformy Organizacji MOST - „POMOST” (Porozumienie Platformy Organizacji MOST - „POMOST”; Lisowski, Sołtys, 2014; Jantura, 2014a).

\section{Programy wyborcze i przebieg kampanii}

\subsection{Prezydent miasta}

Tadeusz Krzakowski kandydując po raz czwarty na prezydenta Legnicy przyjął strategię obrony swojej pozycji. Dwie poprzednie elekcje wygrał już w I turze, z dużą przewagą nad kontrkandydatami. Powszechne było przekonanie, że i tym razem nie da szansy swoim politycznym przeciwnikom.

W kampanii wyborczej odwoływał się do osiagnięć poprzednich kadencji na stanowisku prezydenta miasta, głównie oceniając je poprzez pryzmat zrealizowanych inwestycji. Szczegółowe listy inwestycji z podziałem na lata 2006-2010 i 2010-2014 zamieścił na swojej stronie internetowej. $\mathrm{W}$ pierwszym $\mathrm{z}$ tych okresów podano wizualizację inwestycji przedstawiając mapę miasta wraz z krótkim opisem i zdjęciami. W drugim - wyszczególniono dokładne kwoty nakładów w obszarach takich jak: 1) transport i łączność, 2) oświata, 3) gospodarka mieszkaniowa, 4) kultura fizyczna, sport, turystyka, 5) kultura i ochrona dziedzic- 
twa narodowego, 6) gospodarka komunalna i ochrona środowiska. Do powyższego zestawienia dołączono trzy grupy inwestycji: 1) inwestycje realizowane w ramach inicjatyw lokalnych z udziałem spółdzielni mieszkaniowych, 2) inwestycje realizowane w ramach Legnickiego Budżetu Obywatelskiego, 3) inwestycje spółek komunalnych. Stronę internetową z danymi finansowymi przygotowano w sposób przejrzysty i łatwy w nawigowaniu. Kandydat mógł w ten sposób przeciwstawić się argumentom przeciwników politycznych, którzy twierdzili, że prezydent nie dba o sprawy ważne dla miasta. Jednak nie w każdej sytuacji zestawienie finansowych wydatków było pomocne. Nie broniło prezydenta chociażby przed zarzutem o zbyt małym wykorzystywaniu na inwestycje środków zewnętrznych, spoza budżetu miasta. Porównanie wielomilionowych kwot z wielkością Legnickiego Budżetu Obywatelskiego również mogło rodzić wątpliwości, czy prezydent rzeczywiście chce udziału mieszkańców miasta w kształtowaniu jego przestrzeni (Strona internetowa Tadeusza Krzakowskiego (na potrzeby wyborów w roku 2014)).

Tadeusz Krzakowski stale prowadzi drugą stronę internetową, jako oficjalną stronę prezydenta miasta Legnica (Strona internetowa Tadeusza Krzakowskiego (jako prezydenta Legnicy)). Poza informacjami biograficznymi na swój temat umieścił tam także wiele danych na temat funkcjonowania miasta. W dziale Raporty znajduje się link przekierowujący zainteresowane osoby do strony Biuletynu Informacji Publicznej Urzędu Miasta w Legnicy, a także materiały zawierające raporty roczne i kadencyjne prezydenta miasta ( $\mathrm{w}$ formie plików pdf) począwszy od roku 2003 (Strona internetowa Biuletynu Informacji Publicznej Urzędu Miasta w Legnicy). Dla osób dociekliwych ta druga strona internetowa mogła stanowić ważne uzupełnienie informacji.

Istotną dla przebiegu kampanii wyborczej w roku 2014 była jeszcze inna forma komunikacji medialnej z potencjalnymi wyborcami. Tadeusz Krzakowski umiejętnie komunikuje się z mieszkańcami miasta za pośrednictwem swojego profilu na Facebooku. Informacje, jakie tam można odnaleźć, sięgają roku 2010. Stanowią interesujący zapis przebiegu wydarzeń ważnych dla miasta w ocenie jego prezydenta. Nie są to, jak ma to miejsce w przypadku wielu polityków, jedynie komunikaty na potrzeby cyklicznie odbywających się wyborów (Profil Tadeusza Krzakowskiego na Facebooku).

Na początku października 2014 roku KWW Tadeusza Krzakowskiego dopełnił formalności w Państwowej Komisji Wyborczej związanych $\mathrm{z}$ rejestracją list wyborczych na radnych miejskich (Jantura, 2014c). Dwa 
tygodnie później miała miejsce konwencja wyborcza KWW Tadeusza Krzakowskiego. Komitet promowano przy użyciu hasła „Legnica nasza pasja" (Jantura, 2014d). Trzy dni po konwencji zostały ogłoszone wyniki głosowania mieszkańców nad projektami w ramach Legnickiego Budżetu Obywatelskiego (zdecydowano o sfinansowaniu 10 projektów na łączną kwotę 2 mln zł) (Banaszkiewicz, 2014e).

27 października 2014 roku przedstawiono i uchwalono na sesji legnickiej rady miejskiej projekt „Strategii rozwoju Legnicy na lata 2015-2010 Plus" (Strategia). Krótką analizę strategii zamieszczono na stronie internetowej Urzędu Miasta Legnicy: „Strategia ma charakter ofensywny. Konstruuje wizję Legnicy jako miasta innowacyjnego, będącego regionalnym ośrodkiem wzrostu, kształtującego usługi administracji, nauki, zdrowia, kultury, sportu oraz turystyki w wymiarze ponadlokalnym. Dokument wyznacza pięć celów strategicznych: (1) Rozwój nowoczesnej gospodarki opartej na innowacjach oraz podnoszenie atrakcyjności inwestycyjnej miasta, (2) Wzrost znaczenia Legnicy jako regionalnego ośrodka edukacji, kultury, turystki i sportu, (3) Poprawa jakości i warunków życia legniczan, (4) Kształtowanie atrakcyjnej przestrzeni publicznej i zachowanie obiektów dziedzictwa kulturowego, (5) Ochrona i kształtowanie środowiska przyrodniczego. Każdemu z nich przypisane zostały liczne cele operacyjne, a im z kolei bardzo już konkretne zadania (np. inwestycje drogowe, infrastrukturalne, społeczne, rekreacyjne itd.) do zrealizowania, ulokowane we wszystkich sferach życia miasta" (Banaszkiewicz, 2014c).

Tadeusz Krzakowski wykorzystywał każdą nadarzającą się okazję do kontaktu z mieszkańcami. A to na przykład informował o zakupie nowego autobusu dla Miejskiego Przedsiębiorstwa Komunikacyjnego, a to o zakończeniu remontu osiedlowych ulic.

W mediach przekazano informację, że zakup autobusu jest „realizacją konsekwentnej polityki prezydenta Tadeusza Krzakowskiego, nastawionej na unowocześnianie taboru miejskiego przewoźnika i zakup nowoczesnych, przyjaznych dla pasażerów i środowiska oraz bezpiecznych autobusów" (Banaszkiewicz, 2014d). O remoncie napisano: „Zgodnie z zapowiedzią kolejne ulice na osiedlu Kopernik - Galaktyczna i Plutona zostały gruntownie przebudowane. Powstały tu wygodne jezdnie, chodniki i parkingi. Budowlańcy kończą drobne roboty porządkowe" (Pietrakowska, 2014).

Był także aktywny, jeśli chodzi o obecność w mediach. Przy czym nie stronił od konfrontacji, czego przykładem może być udział w „Ringu wyborczym”, przygotowanym wspólnie przez Radio Zet i „Gazetę Wro- 
cławską". Przy stoliku ustawionym w centrum miasta usiedli prezydent i prowadzący spotkanie dziennikarz. Przechodzący mieszkańcy mogli kierować dowolne pytania do Tadeusza Krzakowskiego. Rozmawiano o zabytkach, przedszkolach, inwestycjach, ale również o potrzebie likwidacji straży miejskiej, bądź zdefiniowaniu na nowo jej zadań. Padło także pytanie o wciąż obecny w sąsiedztwie miejskiego ratusza pomnik symbolizujący przyjaźń polsko-radziecką, wytknięto prezydentowi niezrealizowanie obietnicy o budowie Muzeum Zimnej Wojny i sali koncertowej (Krzyżanowski, 2014; profil Tadeusza Krzakowskiego na Facebooku).

Dzień Niepodległości w dniu 11 listopada 2014 roku został wykorzystany do zorganizowania Pikniku Patriotycznego. Prezydent miasta zapraszał na Barwny Korowód Niepodległości, historyczne rekonstrukcje, prezentacje wojsk i służb mundurowych, w tym uzbrojenia, sprzętu i wozów bojowych 10. Brygady Kawalerii Pancernej ze Świętoszowa, wyposażenia i sprzętu policji, straży pożarnej i straży granicznej, koncerty, pokazy i degustacje potraw. Program przewidywał także „wypuszczenie w niebo ponad tysiąca balonów z życzeniami dla Polski i Legnicy", warsztaty robienia kotylionów, wspólne śpiewanie pieśni patriotycznych oraz utworzenie przez mieszkańców Legnicy wielkiej „żywej flagi” (Banaszkiewicz, 2014a).

W dniu 13 listopada 2014 roku w „Gazecie Wrocławskiej” ukazał się artykuł na temat sprawności w pozyskiwaniu środków unijnych przez dolnośląskie jednostki samorządu terytorialnego w perspektywie finansowania w okresie 2007-2013 w przeliczeniu na jednego mieszkańca. Wysoka pozycja miasta Legnicy w stworzonym przez dziennikarkę rankingu była okazją do upublicznienia tej informacji na stronie internetowej miasta i profilu Tadeusza Krzakowskiego na Facebooku. Najlepszy wynik uzyskał powiat jeleniogórski ziemski (2868 zł na 1 mieszkańca), następnie powiat kłodzki (2134 zł na 1 mieszkańca), miasto Jelenia Góra (1889 zł na 1 mieszkańca), miasto Legnica (1623 zł na 1 mieszkańca), miasto Wałbrzych (1612 zł na 1 mieszkańca), powiat Lubań (1507 zł na 1 mieszkańca), miasto Wrocław (1445 zł na 1 mieszkańca) i powiat wrocławski ziemski (1429 zł na 1 mieszkańca). Legnica otrzymała dofinansowanie 45 projektów na 49 złożonych aplikacji (Gęsiarz, 2014; Banaszkiewicz, 2014b). Najważniejsze zadania, na które otrzymano wsparcie to: ,przebudowa ulicy Gniewomierskiej jako I etap budowy obwodnicy południowo-wschodniej, wieloaspektowa odnowa zdegradowanych obszarów miejskich w rejonie ulic B. Chrobrego i H. Pobożnego, przebudowa ulic Bydgoskiej i Szczytnickiej, budowa nowoczesnego systemu 
monitoringu wizyjnego, zakup przyjaznych dla środowiska i nowoczesnych autobusów dla komunikacji publicznej, budowa sortowni odpadów komunalnych, uporządkowanie gospodarki wodno-ściekowej w aglomeracji Legnica czy budowa zintegrowanego systemu zarządzania ruchem i transportem publicznym w mieście" (Banaszkiewicz, 2014b).

Na dwa dni przed wyborami Tadeusz Krzakowski zamieścił na swoim profilu na Facebooku apel zachęcający do uczestnictwa w wyborach. Tekst został dobrze przemyślany, autor odwołał się do poczucia odpowiedzialności mieszkańców Legnicy za swoje miasto. Wskazał na wartości demokratyczne i patriotyczne, na obywatelskość i wspólnotowość, na rodzinę i miasto, na wagę udziału w wyborach, na dojrzałość i rozsądek, na budowanie wspólnej przyszłości. Oto jego treść:

„Drodzy Legniczanie!

Wolne, bezpośrednie i powszechne wybory samorządowe są jedną z największych zdobyczy demokratycznej Polski. To święto demokracji w jej lokalnym i regionalnym wymiarze. Udział w wyborach jest ważnym przejawem patriotyzmu i obywatelskiej dojrzałości.

Każdy z nas samodzielnie może zdecydować, jaką wizję rozwoju wybiera dla siebie, dla swej rodziny, dla swojego miasta. Czyniąc to, mamy realny wpływ na losy lokalnej wspólnoty.

W Legnicy ponad 80 tysięcy osób jest uprawnionych do wybierania swych przedstawicieli w samorządzie. Przed każdym stoi możliwość udziału w budowie Legnicy obywatelskiej, w budowie miasta, o którego przyszłości decydują mieszkańcy. Mamy wielki przywilej, ale i obowiązek - głosami wyrażającymi troskę o naszą legnicką wspólnotę - wybrać najlepszych dla Legnicy Radnych Sejmiku Województwa, Radnych Rady Miejskiej i najlepszego dla Legnicy Prezydenta.

Nie pozwólmy, by w tak ważnych sprawach dla każdego legniczanina, zabrakło naszego głosu rozsądku.

Ufam, że w niedzielę 16 listopada 2014 roku w ogromnej większości spotkamy się przy urnach wyborczych.

Apeluję do Państwa o powszechny udział w wyborach samorządowych!

Tadeusz Krzakowski

Prezydent Legnicy"

(Profil Tadeusza Krzakowskiego na Facebooku).

Tadeusz Krzakowski komunikował się z wyborcami za pośrednictwem stron internetowych. Jedna $\mathrm{z}$ nich została stworzona na potrzeby 
wyborów, sygnowana przez KWW Tadeusza Krzakowskiego (Strona internetowa Tadeusza Krzakowskiego (na potrzeby wyborów w roku 2014)), druga - była stroną internetową Tadeusza Krzakowskiego jako urzędującego prezydenta miasta Legnica (Strona internetowa Tadeusza Krzakowskiego (jako prezydenta Legnicy)). Ten sposób komunikowania wydatnie wspierał profil Tadeusza Krzakowskiego na Facebooku. Zaletą tej formy kontaktu była możliwość niemal natychmiastowego zamieszczenia materiału w Internecie (Profil Tadeusza Krzakowskiego na Facebooku). Tadeusz Krzakowski, jako urzędujący prezydent miasta, miał też możliwość publikowania materiałów ważnych dla przebiegu kampanii wyborczej na oficjalnej stronie internetowej miasta Legnica (Portal Urzędu Miasta Legnicy, www.portal.legnica.eu).

Tadeusz Krzakowski próbował docierać do mieszkańców Legnicy również w inny sposób. Stosunkowo często uczestniczył w bezpośrednich spotkaniach z mieszkańcami, na przykład dyskutując o przygotowywanej strategii miasta, pełniąc honory gospodarza organizowanej przez miasto imprezy, rozmawiając z dziennikarzami i przeciwnikami politycznymi podczas debat. Jako urzędujący prezydent i jednocześnie kandydat na prezydenta w kolejnej kadencji był często zapraszany przez media, z czego skwapliwie korzystał. Niezmiernie ważną oprawą kampanii wyborczej, istotnie wspomagającą konsekwentne budowanie wizerunku dobrego gospodarza miasta, było wykorzystanie środków reklamy zewnętrznej. Niewątpliwie Tadeusz Krzakowski był najlepiej „widocznym” kandydatem na prezydenta Legnicy. W czasie kampanii wyborczej na ulicach miast zamieszczone były liczne billboardy oraz plakaty z podobizną, nazwiskiem i hasłem prezydenta. Autobusy komunikacji miejskiej także zostały przyozdobione wizerunkiem Tadeusza Krzakowskiego. Mieszkańcy Legnicy otrzymywali ulotki nakłaniające do oddania w wyborach głosu na prezydenta miasta. Tadeusz Krzakowski uzyskał poparcie w wyborach swojego komitetu, ale równocześnie był kandydatem komitetu SLD - Lewica Razem. Dlatego też mieszkańcy mogli się spotkać z dwoma wzorami ulotek, dwóch różnych komitetów. Na odwrocie ulotki własnego komitetu zamieszczone zostało wezwanie do głosowania, zakończone słowami: „Razem wygrajmy szansę dla Legnicy. To nasza wspólna pasja. Tadeusz Krzakowski”. Na ulotce drugiego komitetu były wypisane jego hasła programowe oraz nazwiska kandydatów do rady miejskiej i sejmiku wojewódzkiego. W centralnym miejscu, pod zdjęciem prezydenta miasta, umieszczono słowa: „Tadeusz Krzakowski. Nasz kandydat na prezydenta Legnicy". 
Kampanię wyborczą wspierały także spoty reklamowe zamieszczone na stronach internetowych kandydata i na jego profilu na Facebooku. W spocie KWW Tadeusza Krzakowskiego pojawiają się kolejno różne osoby, mieszkańcy miasta, wszyscy mówią: „Wybieram Legnicę”. Na końcu spotu pojawia się prezydent i wypowiada hasło: „Wybieramy Legnicę. Legnica to nasza pasja”. W sieci pojawił się także spot z Waldemarem Krzystkiem, udzielającym poparcia prezydentowi.

Mimo tak dużego zaangażowania uzyskany wynik w wyborach nie dał Tadeuszowi Krzakowskiemu zwycięstwa w I turze. Po 2 tygodniach musiał się zmierzyć z najlepszym kontrkandydatem Jarosławem Rabczenko.

Działania kampanijne przed II turą wyborów były kontynuowane. $\mathrm{Na}$ 3 dni przed głosowaniem Tadeusz Krzakowski wysłał do mieszkańców Legnicy niezaadresowany list (Rycina 1), który mogli znaleźć w swo-

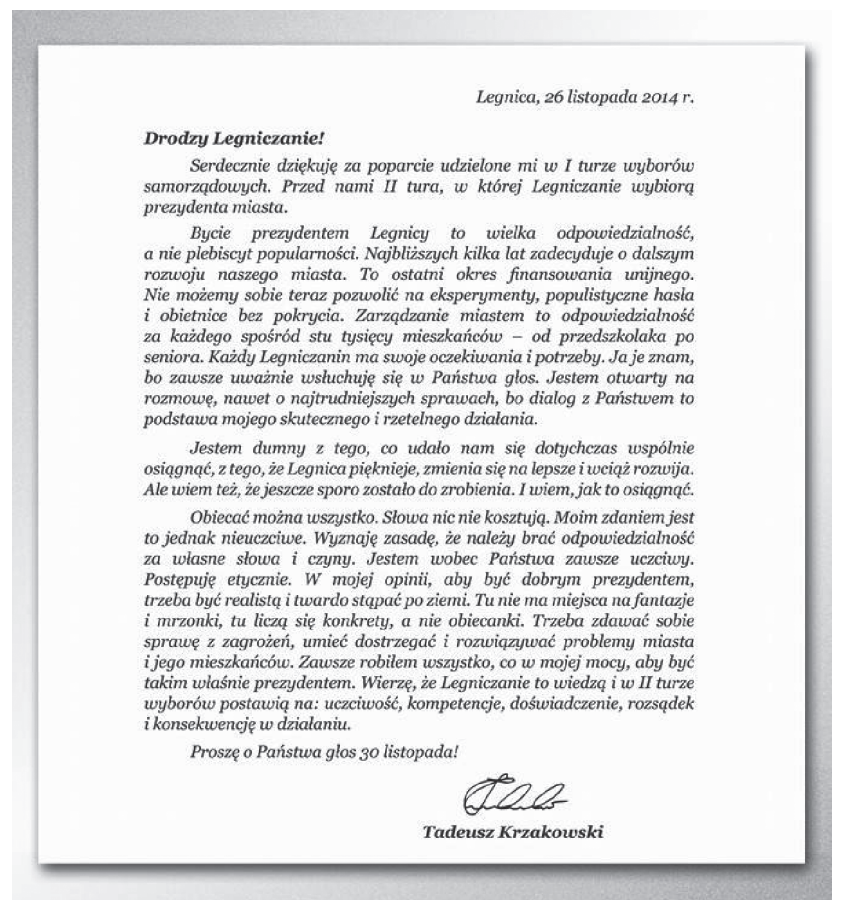

Ryc. 1. List Tadeusza Krzakowskiego do wyborców przed II turą wyborów na prezydenta Legnicy

Źródło: Profil Tadeusza Krzakowskiego na Facebooku, www.facebook.com/pages/Tadeusz-Krzakowski. 
ich skrzynkach pocztowych. Zawierał on podziękowania za udzielone w I turze wyborów poparcie. Odwoływał się do odpowiedzialności, przestrzegał przed populizmem, eksperymentami i składaniem obietnic bez pokrycia. Zwracał uwagę, że w relacjach prezydenta z mieszkańcami ważny jest dialog, który pozwala wspólnie osiagać sukcesy. Deklarował, że prezydent musi być osobą uczciwą przestrzegającą zasad etyki, ale jednocześnie „twardo stapającą po ziemi”. Zaapelował, aby wyborcy postawili na takie cechy, jak „uczciwość, kompetencje, doświadczenie, rozsądek i konsekwencję w działaniu". A na koniec zwrócił się z prośbą o oddanie na niego głosu.

\subsection{Pretendent do urzędu prezydenta miasta}

Najpoważniejszym przeciwnikiem politycznym Tadeusza Krzakowskiego w wyborach na prezydenta Legnicy w 2014 roku okazał się Jarosław Rabczenko. Co prawda Wacław Szetelnicki także zdobył znacząca ilość głosów poparcia w I turze, jednak głosów tych było o 1488 mniej.

Jarosław Rabczenko przygotowywał się do kandydowania w wyborach na prezydenta Legnicy już pod koniec 2013 roku. Ze względu na przetasowania wewnątrzpartyjne $\mathrm{w}$ dolnośląskich strukturach Platformy Obywatelskiej sytuacja przez długi czas nie była klarowna. W mediach pojawiły się nagrania rozmów radnego PO Pawła Frosta z politykami partii. O kierownictwo nad dolnośląskimi strukturami Platformy Obywatelskiej rywalizowali Grzegorz Schetyna i Jacek Protasiewicz (Sołtys, 2014). Partyjne poparcie dla kandydatury Jarosława Rabczenki nie było jeszcze przesądzone. Dosyć istotnym problemem okazały się nieprawidłowości w Agencji Rozwoju Regionalnego „Arleg” S.A., które wiosną 2014 roku były już szeroko komentowane. W czerwcowych wydaniach „Gazety Wyborczej” ukazały się artykuły zawierające analizy powiązań personalnych osób zarządzających spółką „Arleg” i osób będących właścicielami podmiotów prywatnych (Harłukowicz, 2014a; 2014b). W tym samym czasie tygodnik „Wprost” upublicznił nagrania, które dały początek tzw. ,aferze podsłuchowej” (Afera podstuchowa).

Jarosław Rabczenko kandydował z komitetu Porozumienie dla Legnicy. Zostało ono zawarte przez legnickich polityków Platformy Obywatelskiej, Polskiego Stronnictwa Ludowego i członków Fundacji Jacka Głomba „Naprawiacze świata” (Jantura, 2014b). Osoby, które nie znały wcześniej kandydata, mogły nie łączyć jego nazwiska z funkcją wice- 
przewodniczącego partii. Ze względu na zaistniałe okoliczności ważnym punktem w strategii kampanii wyborczej było unikanie łączenia nazwiska kandydata z szyldem partyjnym Platformy Obywatelskiej.

Z początkiem roku 2014 Fundacja Jacka Głomba „Naprawiacze świata" rozpoczęła konsultacje z mieszkańcami Legnicy na temat opracowywanego „Projektu strategii dla Legnicy na lata 2014-2020” (Projekt). Krótko po rozpoczęciu konsultacji w mieście pojawiły się billboardy z hasłem „Obywatelska strategia rozwoju Legnicy” wraz z nazwiskiem i zdjęciem Jarosława Rabczenki (Obywatelska). Osoby niezainteresowane przebiegiem prac nad strategią i nie rozpoznające Jarosława Rabczenki miały dzięki temu komunikatowi kojarzyć go jako koordynatora prac nad strategią.

Oficjalna inauguracja kampanii Jarosława Rabczenki jako kandydata na prezydenta miała miejsce 14 czerwca 2014 roku. Spekulacje na ten temat pojawiły się jednak znacznie wcześniej. Ważnymi kanałami komunikacji polityka z wyborcami były strona internetowa i jego profil na Facebooku (Strona internetowa Jarosława Rabczenki; Profil Jarosława Rabczenki na Facebooku). W zasadzie zaczęły one funkcjonować dopiero wraz z rozpoczęciem kampanii.

Jarosław Rabczenko używał kilku haseł reklamowych. Na długo przed ogłoszeniem informacji o kandydowaniu budował swoją rozpoznawalność wokół tworzenia „Obywatelskiej strategii rozwoju Legnicy”. Pytany o kandydowanie na prezydenta Legnicy, odpowiadał, że nie potwierdza tej informacji, ale też jej nie zaprzecza. Hasła, jakie pojawiły się w kampanii, to: „Zmieńmy Legnicę”, „Razem zmieniamy Legnicę”, „Nowa jakość. Nowa energia".

W strategii prezentowanej przez Jarosława Rabczenkę wyróżniono pięć obszarów: (1) infrastrukturę, (2) gospodarkę, (3) sport i rekreację, (4) kulturę i turystykę, (5) edukację. W ramach rozwoju infrastruktury zaproponowano: dokończenie budowy obwodnicy, budowę parkingów, remonty dróg osiedlowych, rewitalizacje, remonty i termomodernizacje kamienic i bloków mieszkalnych, zagospodarowanie podwórek i placów. Rozwój gospodarczy miasta miałby nastąpić dzięki wspieraniu przedsiębiorczości lokalnych podmiotów, poszukiwaniu nowych inwestorów, uzbrojeniu nowych terenów inwestycyjnych. Wsparcie sportu i rekreacji odbyłoby się w wyniku budowy ogólnodostępnego kompleksu basenowego oraz rewitalizacji Lasku Złotoryjskiego. W ramach rozwoju w zakresie kultury i turystyki zaplanowano adaptację budynku byłego kina „Ognisko” na salę koncertową i utworzenie Legnickiej Orkiestry Symfo- 
nicznej, utworzenie Muzeum Zimnej Wojny i adaptację Teatru Letniego na cele kulturalno-rekreacyjne, opracowanie programu animacji dla ulicy Najświętszej Marii Panny i Rynku, ogłoszenie konkursów na projekty organizacji pozarządowych, utworzenie centrum spotkań młodzieży z krajów historycznie związanych z Legnica, opracowanie programu uczynienia Zamku Piastowskiego atrakcją turystyczną miasta i regionu. W sferze edukacji propozycje dotyczyły utworzenia programu stypendialnego dla szczególnie uzdolnionych legniczan oraz opracowania i wdrożenia programu edukacyjnego w zakresie budowania tożsamości lokalnej (Obywatelska).

W dniu 31 lipca 2014 roku Jarosław Rabczenko rozpoczął cykliczne spotkania z mieszkańcami Legnicy pod hasłem „Ożyw z nami legnickie podwórka!". Miały one miejsce co 3 do 4 dni na dużych osiedlach, placach zabaw, boiskach przy szkołach. Przebieg tych spotkań za każdym razem był podobny. O ustalonej godzinie rozpoczynała się zabawa, polegająca na zachęcaniu gromadzących się mieszkańców przez animatorów do aktywności. Dla dzieci i młodzieży prowadzone były zabawy i gry sportowe, konkursy z drobnymi nagrodami. Stałym punktem tych spotkań były także dyskusje nad strategią dla miasta. Jarosław Rabczenko przedstawiał jej najważniejsze punkty. Zgromadzeni mieszkańcy byli dzieleni na zespoły, mogli zgłaszać swoje własne pomysły, proponować rozwiązania problemów. Wieczorem, gdy zbliżał się zachód słońca, rozpoczynał się pokaz filmu ,Jack Strong”, kręconego na ulicach Legnicy. Spotkania odbywały się kolejno na osiedlach przy ulicach: Senatorskiej, Asnyka, Tatrzańskiej, Wileńskiej, Lwowskiej, Neptuna. Wprowadzenie przez Rosję embarga na polskie owoce i warzywa było okazją do zorganizowania happeningu, polegającego na rozdawaniu spotkanym przechodniom jabłek, rozmawianiu o problemach i zachęcaniu do uczestnictwa w nadchodzących wyborach samorządowych. Zwyczaj częstowania mieszkańców owocami kontynuowano w czasie późniejszych spotkań (Strona internetowa Jarosława Rabczenki).

W staraniach o prezydenturę Legnicy wsparli Jarosława Rabczenkę politycy Platformy Obywatelskiej, przede wszystkim Grzegorz Schetyna, Andrzej Halicki i Bogdan Zdrojewski, ale także wicemarszałek województwa dolnośląskiego Jerzy Michalak. Przed II turą wyborów z wizytą do Legnicy przyjechała minister kultury i dziedzictwa narodowego Małgorzata Omilanowska, a także premier Ewa Kopacz. Na profilu kandydata na Facebooku pojawiła się lista nazwisk wspierających jego starania, zatytułowana Komitet Poparcia Jarosława Rabczenki - kandydata na pre- 
zydenta Legnicy. Z każdym dniem nazwisk było coraz więcej. Osoby te fotografowały się trzymając przed sobą duże kartki z hasłami: „Wybieram rozwój! Głosuję na Rabczenkę!”, „Zależy mi na Legnicy! Głosuję na Rabczenkę!”, „Czas na zmiany! Rabczenko z nami!” (Profil Jarosława Rabczenki na Facebooku).

Jarosław Rabczenko odwoływał się do różnego elektoratu. Pamiętał o ludziach młodych, zwracał się też do seniorów, uczestniczył w spotkaniach $\mathrm{z}$ różnymi środowiskami. Był częstym gościem mediów, uczestniczył w debatach z kontrkandydatami. Rozmowy z nim zamieszczane były w „Gazecie Legnickiej”, na portalu lca.pl i udostępniane przez legnicką Telewizję DamiTV. Przedstawiał interesujące pomysły, warte rozważenia. Deklarował na przykład zrealizowanie projektów, które nie przeszły kwalifikacji w ramach Legnickiego Budżetu Obywatelskiego. Stwierdził, że są to projekty ważne dla mieszkańców, a stanowią niewielki koszt około $4 \mathrm{mln}$ zł.

Poza spotkaniami z mieszkańcami i aktywnością w mediach Jarosław Rabczenko wykorzystywał także środki reklamy zewnętrznej. Ilość billboardów i plakatów z jego podobizną była jednak zdecydowanie mniejsza w porównaniu $\mathrm{z}$ wszędzie widocznymi wizerunkami Tadeusza Krzakowskiego. Mimo że Jarosław Rabczenko nie wskazywał w materiałach swojej przynależności partyjnej, kolorystyka była zachowana. Miało to znaczenie w przypadku wspólnych ulotek z kandydatami na radnych miasta i radnych województwa.

Jarosław Rabczenko na tydzień przed I turą wyborów wystosował do mieszkańców Legnicy pismo. Zwrócił w nim uwagę na kilka ważnych kwestii. Najpierw przekonywał, że Legnica jest jego rodzinnym miastem, z którym czuje się emocjonalnie związany i z którym wiąże swoją przyszłość. Następnie przedstawił w krótkim zarysie negatywne zmiany w Legnicy w czasie ostatnich kilku lat i zaproponował rozwiązania. W trzecim akapicie stwierdził, że wie jak się pozyskuje środki z Unii Europejskiej i zadeklarował, że to zrobi jako prezydent miasta. Poprosił mieszkańców, aby mu zaufali i zapewnił: „Wasza wizja Legnicy to moja wizja Legnicy”. Poniżej zamieszczono kopię pisma.

Na krótko przed II turą wyborów Jarosław Rabczenko także skierował do mieszkańców Legnicy list. Zawierał on podziękowania za oddane na kandydata głosy w I turze. Odwoływał się do poczucia wspólnoty, ale równocześnie stwierdzał „możemy się różnić poglądami politycznymi”. Deklarował, że jako prezydent będzie wsłuchiwał się w opinie obywateli, o co urzędujący prezydent nie dbał. Dziękował za wsparcie i obiecywał ciężką pracę i starania o rozwój miasta. Napisał między innymi: „Moje 
wyzwanie ma na imię Legnica, piękne i dumne miasto, które chcę zmieniać i rozwijać razem z Wami”. W ostatnim zdaniu poprosił o oddanie na niego głosu w II turze wyborów. Na ryc. 3 zamieszczono kopię pisma.

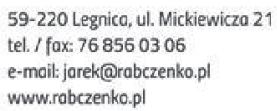

Legnica, 10 listopada 2014 r.

\section{Szanowni Pañstwo,}

Już niebowem wybory samorządowe. No pewno usłyszycie kolejne obietnice, przemowy, reklamy, ale gdybym miał okazję usiq̨ść z każdym z Was opowiedziałbym Wam moją historię. Legnica to cały mój świat. Tutaj się urodziłem i wychowałem. Tutaj poznałem mojq̨ żonę tutaj urodziły się nasze dzieci. Mam wiele powodów, żeby kochać Legnicę. To tutaj żyję I pracuję, jakkażdy z Was. I jak każdy chcę, by Legnica sięrozwijała.

W ostatnich latach Legnica straciła 10000 mieszkańców. Musimy powstrzymać wyjazdy naszych rodzin, przyjaciöł i znajomych. Możemy to osiągnąć poprzez stworzenie nowych miejsc pracy, wsparcie legnickich przedsiębiorców, budowę nowych mieszkań komunalnych, zwiększenie miejsc w żłobkach i przedszkolach. Zamierzam zrezygnować ze stanowisk wiceprezydentów, to niepotrzebne stanowiska dla polityków, a zaoszczędzone środki przeznaczymy na budowę nowoczesnego Domu Seniora.

Do realizacji naszych zamierzeń musimy pozyskać środki z Unii Europejskiej. To ostatnia szansa na przyspieszenie rozwoju Legnicy. Wiem, jak to zrobić. Wraz z moimi współpracownikami pozyskališmy dla naszego regionu ćwierč miliarda złotych z funduszy europejskich! Ale to dopiero początek. Wspólnie osiq̨gniemy jeszcze więcej. Jak? Ciężkq̨ pracq, energiq̨, rozmowq̨, uważnym wsłuchiwaniem się w Wasze, mieszkańców Legnicy, potrzeby. Jestem pewny, że nam się uda, bo Wasza wizja Legnicy to moja wizja Legnicy. Dlatega kandyduję na urzq̨d Prezydenta. By razem z Wami zmieniać Legnicę. Aby stała się miastem przyjaznym młodym i seniorom, przedsiębiorcom i ludziom kultury.

Zaufajcie mi proszę 16 listopada.

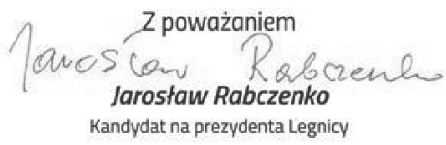

Ryc. 2. List Jarosława Rabczenki do wyborców przed I turą wyborów na prezydenta Legnicy

Źródło: Profil Jarosława Rabczenki na Facebooku, www.facebook.com/rabczenko. 
Legnica, 28 listopada $2014 r$.

\section{Drodzy Legniczanie!}

Serdecznie dziękuję wszystkim, którzy 16 listopada w I turze wyborów prezydenckich zagtosowali za potrzebq zmiany w Legnicy. Tworzymy wielka wspólnotę, wspólnotę ludzi, którzy umitowali naszé miasto i pragnq̨ tchnq̨ć $w$ nie nowq jakość, nowq energię. Możemy różnić się poglądami politycznymi lub szczegótowymi pomystami, ale ta potrzeba zmiany jest najważniejsza.

Rozmawialiśmy o niej często podczas spotkań $w$ trakcie kampanii wyborczej. Często styszalem: "to trzeba zmienic" $i$ byt to dowód, ze przez lata nikt Was nie shuchal, że istota demokracji, która polega na tym, ze glos obywatela musi być wystuchany, nie była przestrzegana.

Jako prezydent Legnicy zmienię to. Przez cała kampanię wshchiwatem się $w$ głos Legniczan $i$ będę to czynić nadal. Bo lider jest ważny, ale najważniejsza jest drużyna, zespót. Chcę być prezydentem wszystkich legniczan, $i$ sprawować urząd prezydenta $w$ dialogu z mieszkańcami Legnicy.

Dziękuję Wam za dobre stowa w kampanii, za wsparcie, jakie spotykatem wlaściwie na każdym kroku. To dla mnie wielkie zobowiazanie $i$ wielkie wyzwanie. Ale czym byloby prawdziwe zycie bez podejmowania wielkich wyzwań? Moje wyzwanie ma na imie Legnica, piękne i dumne miasto, które chce zmieniać i rozwijać razem z Wami. Będę ciężko pracowat, żeby nie zawiesć Waszego zaufania.

Zaufajcie mi. Proszę o glos 30 listopada $w$ II turze wyborów prezydenckich, Razem zmienimy Legnicę!

Jarostaw Rabczenko

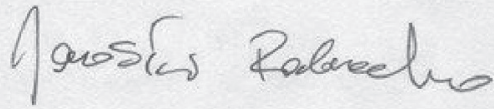

Ryc. 3. List Jarosława Rabczenki do wyborców przed II turą wyborów na prezydenta Legnicy

Źródło: Profil Jarosława Rabczenki na Facebooku, www.facebook.com/rabczenko.

Treść pierwszego listu Jarosława Rabczenki wydaje się zdecydowanie bardziej przekonująca. Wynika ze zdecydowanej postawy kandydata 
w czasie kampanii. Możliwe że cel minimalny, uznawany za satysfakcjonujący, został osiagnięty już w I turze wyborów. Jarosław Rabczenko zmusił Tadeusza Krzakowskiego do rywalizacji w II turze wyborów oraz uzyskał mandat radnego miasta. Za błędne założenia w treści drugiego listu należałoby uznać stwierdzenia, że kandydat może mieć inne poglądy polityczne niż wyborca, oskarżenia urzędującego prezydenta o brak kontaktu z mieszkańcami, sformułowania brzmiące jak pożegnanie w czwartym akapicie listu. List o tej treści miał znacznie mniejszy emocjonalny ładunek mobilizujący do głosowania na kandydata, a nawet mógł przynieść efekt odwrotny od zamierzonego. Puryści językowi mogli dostrzec w końcowej części pisma „literówkę”.

\section{Podsumowanie}

Rywalizacja wyborcza w Legnicy w 2014 roku pomiędzy kandydatami na prezydenta miała interesujący poznawczo przebieg. Obaj kandydaci zainaugurowali swoje kampanie wyborcze stosunkowo wcześnie. We wszystkich sondażach przewidywano zwycięstwo Tadeusza Krzakowskiego. Rozpoczęcie kampanii przez Jarosława Rabczenkę wiązało się z kilkoma dosyć istotnymi problemami. Najpoważniejszym był spór o przywództwo w dolnośląskich strukturach partii pomiędzy Grzegorzem Schetyną i Jackiem Protasiewiczem. Sytuacja ta powodowała trudności z wyłonieniem kandydata na prezydenta Legnicy, a później z potwierdzeniem poparcia partii dla Jarosława Rabczenki.

Przygotowanie do kampanii wyborczej i aktywność obu kandydatów należy ocenić bardzo pozytywnie. Tadeusz Krzakowski umiejętnie wykorzystywał atut sprawowania urzędu prezydenta, inicjował i uczestniczył w różnego rodzaju imprezach, był obecny w mediach, chętnie spotykał się z mieszkańcami, nie unikał bezpośrednich strać z przeciwnikami politycznymi (Debata kandydatów; Debata prezydencka). Jarosław Rabczenko był nie mniej aktywny, miał jednak trudniejsze zadanie. Punkt wyjściowy kampanii był zupełnie inny. Na jego niekorzyść oddziaływały przede wszystkim dużo mniejsza rozpoznawalność, problemy wewnątrzpartyjne, nagłośnienie tzw. afery podsłuchowej. Pełnienie funkcji wiceprzewodniczącego legnickich struktur partii i jednocześnie unikanie partyjnego szyldu mogło budzić wątpliwości.

Przebieg kampanii wskazuje, że pretendentowi zależało na wygranej w wyborach. Wsparcie zaplecza partyjnego, tak ważne przecież w kam- 
panii, nie zawsze jednak spełniało swoje zadanie. Wyraźnie zauważalna była różnica w intensywności wykorzystywanych środków oddziaływania perswazyjnego, przede wszystkich reklamy zewnętrznej. Tłumaczenie, że kandydujący ponownie prezydent wcześniej zarezerwował miejsca, w których możliwe było ich umieszczenie, wskazywało na bezradność sztabu Jarosława Rabczenki. Czy osiągnięcie zakładanego minimalnego celu w I turze wyborów spowodowało mniejsze zaangażowanie w dalszej części kampanii? Wiele na to wskazuje.

\section{Bibliografia}

Afera podstuchowa (2014), „Wprost”, nr 25, http://www.wprost.pl/ar/452372/Aferapodsluchowa.

Banaszkiewicz M. (2014a), Legnica będzie świętować Niepodległość, 6.11.2014, Portal Urzędu Miasta Legnicy, www.portal.legnica.eu.

Banaszkiewicz M. (2014b), Legnica wśród dolnoślaskich liderów pozyskiwania środków unijnych, 13.11.2014, Portal Urzędu Miasta Legnicy, www.portal.legnica.eu.

Banaszkiewicz M. (2014c), Rada Miejska uchwalita Strategię Rozwoju Legnicy, miejscowe plany aktywizujace gospodarke $i$ większe naklady na inwestycje, 27.10.2014, Portal Urzędu Miasta Legnicy, www.portal.legnica.eu.

Banaszkiewicz M. (2014d), Solaris z najwyższej ekologicznej pótki dla legniczan, 29.10.2014, Portal Urzędu Miasta Legnicy, www.portal.legnica.eu.

Banaszkiewicz M. (2014e), Znamy już wyniki glosowania legniczan w II edycji LBO, 24.10.2014, Portal Urzędu Miasta Legnicy, www.portal.legnica.eu.

Debata kandydatów na prezydenta Legnicy, 26.11.2014, zapis dostępny na: Twój Portal Internetowy lca.pl, http://video.lca.pl/play,5FGzLVgw5DA,Video_z_Legnicy.phtml.

Debata prezydencka T. Krzakowski vs. J. Rabczenko, 27.11.2014, specjalne wydanie programu „Musimy porozmawiać” TVP Wrocław, zapis dostępny na Portalu YouTube.com, https://www.youtube.com/watch?v=PVaWbIzX4wg.

Drzonek M. (2013), Reelekcje prezydentów miast w wyborach bezpośrednich w Polsce, Kraków.

Ilciów A. (2015), Pretendenci do prezydentury w wyborach samorzadowych na Dolnym Ślasku w 2014 roku, tekst przygotowany na potrzeby konferencji; Międzynarodowa Konferencja Naukowa „25 lat samorządu terytorialnego w Polsce - bilans doświadczeń", UMCS, Lublin, 8-9 VI 2015 (w druku).

Fundacja Jacka Głomba „Naprawiacze świata”, http://naprawiacze-swiata.pl/fundacja.

Gęsiarz K. (2014), Dolnoślascy liderzy unijnego wsparcia, „Gazeta Wrocławska”, 13.11.2014. 
Harłukowicz J. (2014a), Koniec Platformy w Legnicy po aferze w Arlegu? Decyzja w poniedziatek, „Gazeta Wyborcza”, 23.06.2014.

Harłukowicz J. (2014b), Polityczny układ legnicki, „Gazeta Wyborcza - Wrocław” 20.06.2014.

Jantura P. (2014a), Kongres Nowej Prawica ma kandydata na prezydenta, 16.09.2014, Twój Portal Internetowy lca.pl, http://fakty.lca.pl.

Jantura P. (2014b), Opozycyjna koalicja popiera Rabczenkę, 21.07.2014, Twój Portal Internetowy lca.pl, http://fakty.lca.pl.

Jantura P. (2014c), Prezydencki komitet zwarty i gotowy do wyborów, 6.10.2014, Twój Portal Internetowy lca.pl, http://fakty.lca.pl.

Jantura P. (2014d), Tadeusz Krzakowski ruszył z kampaniq wyborczq, 19.10.2014, Twój Portal Internetowy lca.pl, http://fakty.lca.pl.

Krzyżanowski P. (2014), Tadeusz Krzakowski pod ostrzałem pytań w Legnicy, 4.11.2014, Portal Informacyjny Legnica.naszemiasto.pl, http://legnica.naszemiasto.pl.

Lisowski M., Sołtys D. (2014), 27-latek kandydatem Nowej Prawicy na prezydenta, 16.09.2014, Regionalny Portal Informacyjno-Publicystyczny e-legnickie.pl, http://e-legnickie.pl.

Obwieszczenie komisarza wyborczego we Wroctawiu z dnia 1 grudnia 2014 r. uzupetniajace obwieszczenie z dnia 22 listopada 2014 r. (tekst jednolity Dz. U. 2014, poz. 5116) o wynikach wyborów wójtów, burmistrzów i prezydentów miast na obszarze województwa dolnoślaskiego, http://wroclaw.pkw.gov.pl/g2/oryginal/2014_12/d4d5c666536bd39a2915849d75864dc8.pdf.

Obywatelska strategia rozwoju Legnicy, 20.03.2014, dokument w postaci pliku pdf oraz prezentacja multimedialna w programie Prezi Desktop, strona internetowa Jarosława Rabczenki, http://rabczenko.pl.

Pietrakowska E. (2014), Nowe ulice na Koperniku, 3.11.2014, Portal Urzędu Miasta Legnicy, www.portal.legnica.eu.

Porozumienie Platformy Organizacji MOST - „POMOST”, 22.06.2015, Portal Urzędu Miasta Legnicy, www.portal.legnica.eu.

Profil Jarosława Rabczenki na Facebooku, www.facebook.com/rabczenko.

Profil Tadeusza Krzakowskiego na Facebooku, www.facebook.com/pages/TadeuszKrzakowski.

Profil Wacława Szetelnickiego na Facebooku, www.facebook.com/w.szetelnicki.

Projekt strategii dla Legnicy na lata 2014-2020, 6.02.2014, Fundacja Jacka Głomba „Naprawiacze świata”, http://naprawiacze-swiata.pl.

Skrzypiński D. (red.) (2012), Rywalizacja o prezydenturę w miastach Dolnego Ślaska, Wrocław.

Sołtys D. (2014), Alfabet legnicki roku 2013, 6.02.2014, Regionalny Portal Informacyjno-Publicystyczny e-legnickie.pl, http://e-legnickie.pl.

Strategia rozwoju Legnicy na lata 2015-2010 Plus; strategia ta jest dostępna w postaci pliku pdf na oficjalnej stronie Urzędu Miasta Legnicy, Portal Urzędu 
Miasta Legnicy, www.portal.legnica.eu, www.portal.legnica.eu/legnica2/ web/uploads/emp/pages/page_873/text_images/Strategia_Rozwoju_Miasta Legnicy_2015_2020_plus.pdf.

Strona internetowa Biuletynu Informacji Publicznej Urzędu Miasta w Legnicy, http:// um.bip.legnica.eu.

Strona internetowa Jarosława Rabczenki, http://rabczenko.pl.

Strona internetowa Tadeusza Krzakowskiego (na potrzeby wyborów w roku 2014), http://tadeuszkrzakowski.eu.

Strona internetowa Tadeusza Krzakowskiego (jako prezydenta Legnicy), www.prezydent.legnica.eu.

Strona internetowa Urzędu Marszałkowskiego Województwa Dolnośląskiego, www. umwd.dolnyslask.pl/sejmik/radni-wojewodztwa.

Strona internetowa Wacława Szetelnickiego, http://waclawszetelnicki.pl.

Szymacha D. (2014), Myrda prezydentem Lubina?, 7.03.2014, Regionalny Portal Informacyjno-Publicystyczny e-legnickie.pl, http://e-legnickie.pl.

Szymacha D. (2015), Większa kasa ludzi prezydenta (aktualizacja), 22.06.2015, Regionalny Portal Informacyjno-Publicystyczny e-legnickie.pl, http://e-legnickie.pl.

Tomczak Ł. (red.) (2012), Prezydenci miast. Analiza rywalizacji w wyborach samorzadowych, Wrocław.

Wizualizacja wyborów samorzqdowych, http://pkw.gov.pl/wizualizacja-wyborow-samorzadowych-samorzad-2014/wizualizacja-wyborow-samorzadowych-info.html.

\section{President of Legnica. The election campaign in 2014}

\section{Summary}

The author analyzes in the paper the local elections in 2014. He focuses on competition for the presidency of Legnica between two candidates, the current president Tadeusz Krzakowski and aspiring to the role of president vice-chairman of the local structures of ruling party. The author refers to the programs of both candidates and analyze the campaign. He is looking also for the factors determining the success of the president and the defeat of the pretender.

Key words: local elections, president of the city, Tadeusz Krzakowski, Jarosław Rabczenko 